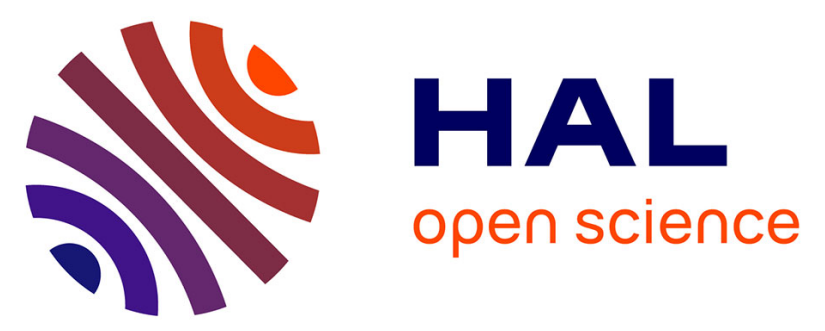

\title{
Carbon Nanotube-Templated Synthesis of Covalent Porphyrin Network for Oxygen Reduction Reaction
}

Ismail Hijazi, Tiphaine Bourgeteau, Renaud Cornut, Adina Morozan, B. Jousselme, Stéphane Campidelli

\section{To cite this version:}

Ismail Hijazi, Tiphaine Bourgeteau, Renaud Cornut, Adina Morozan, B. Jousselme, et al.. Carbon Nanotube-Templated Synthesis of Covalent Porphyrin Network for Oxygen Reduction Reaction. France-Japan Meeting on (bio)-functionalization of nanostructured carbon and (bio)-electrocatalytic applications, Sep 2016, Grenoble, France. cea-02349533

HAL Id: cea-02349533

https://hal-cea.archives-ouvertes.fr/cea-02349533

Submitted on 5 Nov 2019

HAL is a multi-disciplinary open access archive for the deposit and dissemination of scientific research documents, whether they are published or not. The documents may come from teaching and research institutions in France or abroad, or from public or private research centers.
L'archive ouverte pluridisciplinaire HAL, est destinée au dépôt et à la diffusion de documents scientifiques de niveau recherche, publiés ou non, émanant des établissements d'enseignement et de recherche français ou étrangers, des laboratoires publics ou privés. 


\title{
Carbon Nanotube-Templated Synthesis of Covalent Porphyrin Network for Oxygen Reduction Reaction
}

\author{
I. Hijazi, T. Bourgeteau, R. Cornut, A. Morozan, B. Jousselme and S. Campidelli \\ ${ }^{1}$ LICSEN, NIMBE, CEA, CNRS, Université Paris-Saclay, CEA Saclay 91191 Gif-sur-Yvette \\ Cedex, France.
}

The fabrication of functional hybrid materials that preserves and combines the properties of their building blocks is a central issue of nanosciences. Among the different classes of nanomaterials, carbon nanotubes are promising for electronics, catalysis and composite applications. Within the context of sustainable development and renewable energy, we and others envisioned the use of functionalized or doped carbon nanotubes in electrocatalytic systems. ${ }^{1,2}$ In such systems, the catalytic sites need to be supported on conducting materials. Carbon nanotubes, thanks to their electrical conductivity and their high surface area appear as the ideal material for that purpose.

In actual proton exchange membrane fuel cell devices (PEMFC), the reactions at the electrodes and in particular the reduction of oxygen is performed by platinum nanoparticles. The cost of platinum encourages the development of new catalysts based on non-noble metals. In nature, the reduction of oxygen is performed by iron porphyrins in the active center of enzymes. Thus bio-inspired catalysts based on cobalt or iron macrocycles have been extensively studied for oxygen reduction reaction (ORR). ${ }^{3,4}$

Here, we describe the formation of a covalent network of porphyrins around MWNTs. Our approach is based on adsorption of ethynylporphyrins followed by the dimerization of the triple bonds. The nanotube acts as a template for the formation of the polymeric layer. The nanotube hybrids were characterized and tested for the ORR in a series of electrochemical measurements in acidic conditions. Compared to similar systems in which monomeric porphyrins are simply physisorbed, the nanotube hybrib showed a higher activity, a higher current density, a lower overpotential and a four electrons reaction pathway. ${ }^{5}$
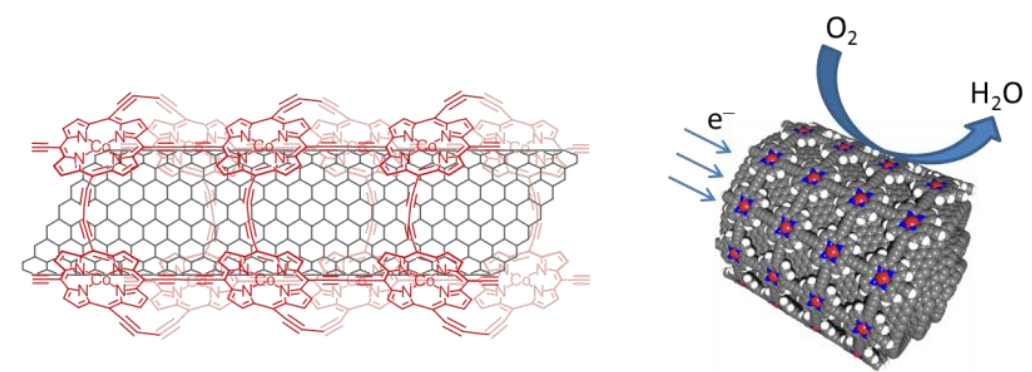

Figure. Representation of a MWNT with cobalt porphyrins polymerized at its surface for oxygen reduction reaction.

$\underline{\text { References }}$

(1) Zhang, W.; Sherrell, P.; Minett, A. I.; Razal, J. M.; Chen, J. Energy Environ. Sci. 2010, 3, 1286-1293.

(2) Morozan, A.; Jousselme, B.; Palacin, S. Energy Environ. Sci. 2011, 4, 1238-1254.

(3) Zagal, J. H.; Griveau, S.; Silva, J. F.; Nyokong, T.; Bedioui, F. Coord. Chem. Rev. 2010, 254, 2755-2791.

(4) Morozan, A.; Campidelli, S.; Filoramo, A.; Jousselme, B.; Palacin, S. Carbon 2011, 49, 4839-4847.

(5) Hijazi, I.; Bourgeteau, T.; Cornut, R.; Morozan, A.; Filoramo, A.; Leroy, J.; Derycke, V.; Jousselme, B.; Campidelli, S. J. Am. Chem. Soc. 2014, 136, 6348-6354. 